\title{
LANGUAGE EDUCATION PROJECTS IN PRIMARY SCHOOL IN GREAT BRITAIN IN THE SECOND HALF OF THE XXth - BEGINNING OF THE XXIst CENTURY
}

\author{
Marianna Cheveliuk \\ Postgraduate Student, Open International University of Human Development "Ukraine", Ukraine \\ e-mail: marianna.cheveliuk@gmail.com,orcid.org/0000-0002-2715-5024
}

\section{Summary}

The article analyzes language education projects in primary school in Great Britain in the second half of the XX - beginning of the XXI century. The aspirations of specialists in the field of language education were aimed at democratizing the educational system in the country. The idea of an early start in teaching foreign languages to students was put forward. During the second half of the century in England, Wales, Scotland, a number of projects were conducted to teach a foreign language at the level of primary education. The implementation of the projects highlighted both the positive features and the difficulties of the initiative.

Teaching foreign languages in primary schools requires consideration of a number of factors, including didactic, psychological aspects, issues of ensuring appropriate teacher training, and so on. In general, the research of British scientists in the field justified the positive assessment of the projects, identifying positive dynamics of student performance in a foreign language, increasing student motivation to study the discipline and a positive attitude to it, expanding the general and educational interests of children; the importance of teaching the subject for general education and development of children, better development of their speech skills and stressed the need for didactic development and pedagogical implementation of foreign language teaching in primary education with continuity and consistency in the curriculum at secondary education, special training for primary school teachers schools for teaching foreign languages.

Keywords: pupil, level, knowledge, school discipline, teacher, goverment, subject

\section{DOI: https://doi.org/10.23856/3833}

\section{Introduction}

In primary schools in Britain until the second half of the twentieth century language education was provided only in the form of the native language. A foreign language was not provided in the curriculum. In the 1960s and 1970s, government agencies, teachers, and scholars challenged views on foreign language learning from elementary school.

An analysis of monographic studies and government documents revealed that the idea of the introduction of foreign language teaching in primary school in Great Britain was first seriously substantiated in the Annan Report in 1962. It stated, in particular: "The benefits of introducing foreign language learning at an early age are that students are thus introduced to idiomatic foreign language expressions at an age when their ability to imitate reaches its peak. Usually an integral condition for success is fluency in the spoken language by teachers and the appropriateness of teaching methods"(Annan, 1962: 32). That is, if teachers are properly trained and implement appropriate teaching methods, initiating foreign language learning for young children will be able to yield significant positive results. 
This idea of early learning of foreign languages was considered appropriate in the early second half of the twentieth century a number of psychologists have done a lot of research on this subject. Thus, a study by Canadian neurosurgeons W. Penfield and L. Roberts in the book "Speech and brain mechanisms", noted that teaching children foreign languages in school should begin somewhere from 4 to 10 years, because at this time the child's brain is more flexible and more able to learn the language (Penfield, Roberts, 1959: 286).

Professor R. Johnstone, Director of the Scottish Center for Foreign Language Information (CILT), wrote about the research conducted in this area: "In terms of development, each age has its own special advantages and disadvantages for language learning and learning. In the 1960s, mistakes were made in anticipation of the magical results of starting to learn a foreign language at an early age. But the miracle did not happen. Although the introduction of foreign language teaching at a later age also does not solve the problem" (Johnstone, 1997: 171-175).

However, another problem was identified, which did not concern the aptitude of students, but their attitude to learning a foreign language as a school discipline. Researcher K. Burstall drew attention to this problem. He was convinced that the peculiarities of the period of sexual growth deepen certain psychological characteristics, especially in boys, which makes the beginning of learning a foreign language by children at the age of 11 extremely unfavorable (Burstall, 1970: 226).

The experimental introduction of foreign language teaching in primary school at the national level was due to the desire to improve the language situation in school education.

On March 13, 1963, Sir Edward Boyle, with the support of D. Morrell, an employee of the Ministry of Education, and LF Brown, director of the Naffield Foundation, which supported the reform of foreign language teaching at all educational levels, announced in parliament the launch of a pilot scheme to determining the possibility of introducing foreign (French) language teaching in primary schools to students from 8 years of age.

The Plowden Committee, founded by Boyle in 1963, believed that the project advocated "old-fashioned" forms and methods of classroom teaching: “... early foreign language learning leads to ... the development of tradition ... classroom teaching and formal lessons" (Plowden, 1967: 555).

However, despite high-profile debates, controversies, and doubts, the pilot scheme gained support and became one of the optimistic hopes for the implementation of the education reforms of the 1960s.

A study by the Naffield Foundation found that in England, Wales and Scotland, 58 local regional education departments in the public sector reported that foreign language teaching was or would be introduced in primary schools at the end of the 1962-1963 school year in 200 schools in England and 80 - in Scotland (Lazaro, 1963:29). Meanwhile, only 18 of the 58 regional education departments provided support for the introduction of a foreign language into the curriculum, while in other regions the initiative for such work belonged to the schools themselves.

In 1963, a foreign language was studied only from the age of 11, but not in all schools, but only in selected grammar schools. Thus, at that time there were serious changes in the regional education authorities in the content of education in both primary and secondary schools.

The country failed to meet the goal of conducting a limited study, as regional education authorities that were not selected for the experiment rejected the exclusion and about 90 more were recognized as "associated regions." This was done in order to prevent self-employment and to ensure compliance with the requirements set by the Ministry of Education, although without a detailed study of the results of the experiment obtained from them. The result was 
the widespread introduction of French in primary schools in the early 1970s. According to scientists, about a third of primary schools in the country have included teaching French in the curriculum (Hoy, 1977: 146).

The most difficult problem, as it turned out later, was the lack of teachers. It was very difficult to train and retrain a large number of primary school teachers.

In 1960, there were only 37 institutions, namely colleges that trained specialists in the relevant French language. Their number grew rapidly and in 1963 reached 63, and in 1971 there were 91 such colleges.

Training courses were organized for teachers who had a high and intermediate grade in French in the General Certificate of Education. This was supported by Her Majesty's Inspectorate and a new corps of foreign language advisers. Thus, a sufficient number of foreign language teachers were trained.

According to E. Hawkins, due to the activities of the National Fund for Pedagogical Research "no school subject has been studied so carefully for a number of years" (Hawkins, 1997: 155-164). The study was conducted on students aged 8 to 11 years. The success of language learning over a period of time was assessed and compared with other components of the curriculum in primary education.

The results of the study of all these aspects were important, but the devastating conclusion made in Burstal's final report that early foreign language learning did not yield significant achievements in mastering a foreign language almost rejected all the fruitful achievements of the project and identified the inappropriateness of its continuation. Such a disappointing official conclusion led to the completion of the project at the national level, and in 1974 the government stopped funding it.

Scholars and educators have sharply criticized Burstall's report, pointing to the vagueness and scientific fallacy of evaluative judgments and calculations. Thus, K. Gumble and A. Smalley, noting other technical shortcomings of the evaluation of the project, indicated that the number of students studied at the beginning of the project was 11,300, and in 1973 - only 1,227, which did not allow to speak of an objective analysis. data (Gamble, Smalley, 1975: 124-129).

The Naffield Foundation was strongly opposed to the termination of the project. He invested heavily in its financing. The National Advisory Committee, led by linguist and former head of the JR Ponter Language Learning Information Center, met to review the project's results and implications. P. Hoy prepared a report, which indicated the interest that this project has aroused in Europe. P. Howe was an inspector of modern languages and had his own experience of the last stages of the pilot scheme. The author of the report said that the results of the pilot scheme were discussed at the Council of Europe seminar in Copenhagen in September 1976. The symposium did not accept the view that the experimentation should be justified, but instead recommended that the Council of Europe continue teaching modern foreign languages to young children at an early age and called for further pilot experiments.

P. Hoy emphasized that in order to succeed in teaching foreign languages at an early age, it is necessary to clearly define the goals and objectives in this area and to clarify the necessary conditions for successful learning by prioritizing, focusing on adequate training of qualified teachers and clear definition of short-term tasks of teaching and learning. He pointed out that the researchers had drawn their own conclusions about the pros and cons of teaching foreign languages in primary schools, ignoring the question of the success of learning and learning French in primary schools, which could lead to a retrospective statement of the results of the experiment. looking ahead, inspiring the development of conditions for the success of such training (Hoy, 1977: 146). 


\section{The main findings of the pilot scheme}

P. Hoy, summarizing the main conclusions of the pilot scheme in a press release of the National Foundation for Pedagogical Research, identified:

- younger children showed a better ability to understand what they heard, to learn to listen;

- they showed a more positive attitude to the conversation in French (foreign); education;

- girls show the best results in learning a foreign language at both primary and secondary

- at the level of secondary education, the introduction of French language teaching in primary education has had a negative impact on the place of other modern foreign languages, provided that French is given the place of the most common foreign language in schools and an increase in the number of students that learning a foreign language is not for them;

- there is a linear relationship between success in mastering the French language and the socio-economic status of students and their families;

- both boys and girls do better in schools with separate education;

- students in small rural schools do better than in large urban schools;

- students in the south of England are more positive about learning French than students in the north of the country;

- the level of success in learning French by students is influenced by the attitude of school management;

- the feeling of success at an early age has a positive effect on further success in old age;

- The biggest stimulus for learning French for students is the opportunity to go to France. If the students were convinced that they would not have to go to France, the students regarded its study as a waste of time;

- children who went to France achieved better learning outcomes than other students (according to the study, the social status of these children was usually quite high, their attitude to learning French was better and to visit the country);

- those who achieved the best results in learning a foreign French language preferred traditional teaching methods, especially negative about the constant use of a tape recorder and reading aloud in French;

- younger students were deterred from learning French by teaching in the classroom only in French without checking its understanding (Hoy, 1977: 146).

P. Hoy's report and the project's conclusions offered an objective assessment of the pilot scheme, but did not help to implement it. They reflected both purely national indicators of foreign language teaching in primary schools and those that can be used and taken into account when initiating foreign language teaching in primary schools in other countries.

\section{Language education projects in Scotland}

In Scotland in the late 1960s and early 1970s, as in England, French was introduced in primary schools. The initiative covered about 500 primary schools and faced similar challenges. In 1969, in the Report of Her Majesty's Inspectorate, based on a review of the educational process of 106 schools, it was noted: 1) the lack of consistency between the content of foreign language teaching in primary and secondary education; 2) insufficient professional level of foreign (French) language proficiency of many primary school teachers. Meanwhile, research by scholars, including J. Nisbet and G. Entvisla, has shown that students who began learning French in elementary school maintained a positive attitude toward learning the subject in high school. They drew their conclusions based on a study of the performance of students in 
the second year of high school. Their research also pointed to the positive features of teaching the discipline on the possibility of expanding the general knowledge and learning interests of students and the development of speech skills (Nisbet, 1970: 192).

In the late 80 's of the twentieth century. The initiative to introduce foreign language teaching in primary school was announced as a national pilot program for foreign language teaching (Modern Languages at Primary School - MLPS). Scottish government officials and politicians saw the introduction of early foreign language learning at school as one of the components of Scottish economic growth and competitiveness in the future, as the idea of creating a common European market spread.

In Scotland, students attend primary school for 7 years and go to secondary school a year later, at the age of 12, than children in England. The national pilot scheme was "launched" in the autumn of 1989 in 6 secondary schools and attached primary schools, which helped to create school complexes (clusters), which facilitated the transition of children to secondary school. Each school complex included several primary and one secondary school. The training in the complex was to facilitate the transition of students to secondary school, given the coherence of curricula and the common policy of foreign language teaching. In 1990, 6 more secondary schools and structurally related primary schools joined the project. Thus, a total of 12 secondary and 76 primary schools were involved in the project.

During the first year, the introduction of a pilot scheme of foreign language teaching was introduced for students aged 11 to 7 , and in subsequent years for children aged 10-11 in the sixth and seventh years of schooling. In a number of schools, foreign language teaching was introduced for students aged 7-8 in the fourth year of study. In addition, in several small primary schools, the introduction of foreign language teaching was carried out from the very beginning in the classes of mixed-age students.

Initially, the project did not involve the introduction of a foreign language into the content of education in all primary schools in Scotland. But the results of the project led to the formation of an agreed assessment by Her Majesty's Inspectorate, advisers, teachers, parents on its approval. In 1992, the Secretary of State for Scotland announced that in 5 years all Scottish primary schools would include foreign language teaching in the curriculum.

The Scottish project from the project carried out in England, noted 4 features. First, the project did not provide for the teaching of all students as a foreign language only in French. Some schools taught German, Spanish, or Italian, which showed an understanding of the importance of language diversity in foreign language teaching. Secondly, the leading feature of foreign language teaching in primary school was the study of language, which is achieved by involving students in various activities by means of a foreign language in order to achieve a serious level of language knowledge and speech skills. Although during the implementation of the project it was recognized as necessary and useful and conscious knowledge of the language to ensure the successful study of a foreign language. Third, it was based on the view that a foreign language in primary school should not be taught as a separate subject, and its study should be "immersed", ie integrated into the curriculum of primary school. And lastly, in most complexes - "primary school + secondary school" - foreign language teaching was to be carried out jointly by class teachers of primary school and teachers-specialists in foreign language of secondary schools. The linguistic qualification of secondary school teachers, therefore, was to be supplemented by pedagogical, methodological, psychological knowledge of primary school teachers, their knowledge of the curriculum and the content of education in primary school.

The Scottish Ministry of Education conducted an independent study of the results of the project to determine the achievements of students involved in the project compared to the 
results of foreign language learning by students who did not learn a foreign language in primary school and analysis of the content of the foreign language course. methods of teaching a foreign language in primary school (Low, Brown, Johnstone, Pirrie, 1995: 5).

The study was conducted in several stages. The first (January 1991 - December 1992) according to experts, based on the analysis of student performance in the late first and second years of high school, students who began learning a foreign language in primary school, showed better results in mastering and learning a foreign language in compared to those who were deprived of such an opportunity. They showed better performance in mastering the phonetic structure of a foreign language, produced longer expressions in a foreign language, showed better motivation to learn a foreign language, showed a more positive attitude to the use of communicative teaching methods, were more willing to communicate in a foreign language in class. The advantages of mastering a foreign language by students of all levels of abilities who started learning it early in comparison with those who started learning it at the level of secondary education, and especially by worse students, were recorded.

At the second stage of the 1993-1995 study, the consequences of the project were analyzed: psychological, pedagogical and methodological issues of teaching and learning a foreign language; student performance; needs of professional development of teachers. Within these areas, three main areas have been identified: language knowledge, learning methods and the transition from primary to secondary education.

Differences between the organization of education in primary and secondary schools were identified, which posed certain problems. Thus, studying a foreign language in primary school, students got acquainted with a very wide range of topics, language structures, activities due to the system of "immersion", which is characteristic of primary school education, and in secondary school the content of education is more regulated by foreign language curriculum. The organization of education in primary schools followed the pedocentric guidelines for the organization of the educational process around the interests of the child, while the educational process in secondary school focused on the subject principle of organization, which made it difficult to maintain systematic and consistent learning. These factors and others needed real consideration and solution in the transition from learning a foreign language at primary to secondary education. But at the end of the pilot project in 1995, they were not fully resolved.

Regarding the degree of success in mastering a foreign language among the studied groups of students, the analysis showed that students involved in the pilot scheme showed higher foreign language proficiency in the first year of secondary school and slightly lower in the second year of secondary education. Although the notion of "better" referred to numbers (for example, the number of lexical units used by students); most of their expressions were idiomatic structures, which they used with little ability to manipulate. The researchers tried to trace the results of learning a foreign language to pilot groups of students before they pass the standard final exams. It was difficult to draw specific conclusions based on the results of the exams of the first pilot group, and yet the data of researchers showed advantages in the success of foreign language students of the pilot scheme compared to those who began to study it in high school (Hotho, 1988).

Following the completion of the project, a process was launched in Scottish primary schools to introduce foreign language teaching as part of the curriculum in all primary schools in the country. This practical implementation contained a significant difference from the pilot scheme: all foreign language teaching was carried out by a primary school teacher. In order to provide primary school teachers with professional linguistic knowledge, speech skills and methodological background, a national foreign language training program for primary school 
teachers has been launched in Scotland. In the 1993/94 academic year, 370 teachers underwent such retraining, in 1994/95 - more than 800 people and more than 800 - in 1995/96.

The introduction of foreign language teaching in primary school has made us think more seriously about the role of the child's native language in the development of foreign language competence. It is now recognized in the country that language knowledge and language proficiency should be an important component of a child's holistic language and speech development, and if an elementary school teacher speaks and can introduce children to more than one language, he or she can provide invaluable assistance.

\section{Unresolved Issues by R. Johnstone in language education}

R. Johnston pointed to the existence of many unresolved issues, including:

1) the number of foreign language-trained teachers that will be required in each primary school;

2) what further training they will receive;

3) who will carry out such training and provide its financing;

4) whether students will always have the right to continue learning a foreign language in secondary school, which they began to learn in primary school, or under the pressure of administrative measures they will be forced to change a foreign language to learn;

5) how primary school teachers will be able to cope if the changes affect another area of the curriculum;

6) how to establish and maintain close ties with secondary schools by primary school teachers;

7) what changes will take place in the curriculum of a foreign language in secondary schools in order to ensure the sequence of learning in the transition from primary school to secondary education (Johnstone, 1997: 174).

Although the researcher asserted with confidence: "As long as there is strong political support for foreign language teaching, which is reflected in the financial provision of schools with the necessary number of teachers, their training and professional development and there is an understanding that the inclusion of a foreign language in the general primary curriculum is a long process - the prospects for this endeavor are quite good"(Johnstone, 1997: 174).

The Scottish experience of teaching a foreign language to primary school children has shown that teaching a foreign language at this level requires teachers to combine language skills and speech skills with training in teaching methods, with an emphasis on those appropriate in primary education. The task of providing a sufficient number of qualified teachers necessitated radical changes in teacher training, namely the introduction of a foreign language as a compulsory component of any primary school teacher training course. But the central government of Great Britain at that time did not take such a position.

In England, following the publication of Burstal's Report on French in Primary School: Attitudes and Achievements and the cessation of public funding for the pilot scheme in 1975, a small number of regional education departments and individual public and private schools continued to experiment with French in primary schools.

These studies of foreign language teaching in primary schools in the UK allowed P. Satchwell to conclude about the ability and positive attitude of younger students to learn foreign languages, which was seriously underestimated even in the recent past and to say that: children did not consider learning a new language difficult, adults sometimes exaggerated the difficulties in matters that did not pose serious problems for children; even five-year-olds are able to learn quite 
complex topics by means of a foreign language, if the language is presented in an interesting and exciting way; it is necessary to revise the approaches to curriculum development and scheduling in primary schools and, in particular, in relation to a foreign language (Satchwell, 1997: 169).

P. Satchwell emphasized that:

- teaching a foreign language twice a week is insufficient and recommended to refer to the experience of Scots who tried to include foreign language learning in everyday schooling in order to train language structures in a variety of learning situations in teaching arithmetic, music, aerobics, art, etc.;

- one of the consequences of the introduction of foreign language learning by all students was to improve listening skills, better understanding of the language - both native and foreign, improve self-confidence, self-balance, improve social skills through the use of pair, group work, dramatization, deeper penetration into the life and culture of other peoples;

- learning a foreign language was an important experience and an important part of children's general education, which was confirmed by the results of a number of projects in the UK, other European countries, Canada and Australia. Children under the age of 10 quickly learn a new language and use it creatively for their own purposes. They are interested in acquaintance with the culture and life of children in other countries, they enthusiastically study poems, songs, dramatize with the accuracy and correctness of pronunciation and intonation, if from the very beginning it is aimed at learning a foreign language;

- Not everyone can become a foreign language teacher in primary school. The country considered that a primary school teacher did not need to have a language degree, but needed a qualification defined within the "competencies" defined, for example, by the Scottish Office for Education (SOED) in the Teacher Retraining Program (1994). Special pedagogical training cannot be acquired at night or in distance learning, teachers need intensive training with the help of qualified tutors and teacher advisors (Satchwell, 1997).

The researcher emphasized that the quality and success of children's foreign language learning and their attitude to a foreign language depends on the personality and competence of the primary school teacher, in which the experience of Scottish initiatives was very important and positive.

\section{Conclusions}

Study and analysis of pedagogical experience in the implementation of pilot schemes for teaching foreign languages in primary schools in the UK in the second half of the twentieth century show the idea of the appropriateness of including the teaching of a foreign language in the content of the curriculum of primary schools in Great Britain spread from the 60s of the twentieth century with the strengthening of the movement of educational reforms aimed at democratization of the country's educational system and its components.

Scientific, technical, technological advances of developed countries have attracted the attention of governmental organizations and the general public to the need to study foreign best practices and theoretical developments and highlighted the importance of foreign language skills, which provides rapid adequate study of the latest data, information exchange, communication.

Specialists in the field - scholars, teachers - could not agree with the short-sighted attitude to learning a foreign language in the country and made efforts to convince the government and government agencies and the general public of the importance of introducing foreign language teaching at all levels of school education. The result of their activities was the launch of a pilot scheme for foreign language teaching in primary schools in England. 
Although the pilot scheme implemented in England did not receive a favorable decision at the state level, its results convinced supporters and propagandists of the idea of the practical usefulness of early foreign language learning. The cessation of official funding and the completion of a pilot project on the introduction of foreign language teaching in primary schools in England did not stop activists, some regional education departments from further experimental practical pedagogical activities to implement early schooling for foreign school children.

The Scottish pilot scheme confirmed the positive results of foreign language learning in primary school, encouraged the Scottish Ministry of Education to decide on the feasibility of introducing foreign language learning in primary education, taking into account a number of recommendations, including the desire to diversify foreign language learning. integration of foreign language teaching into the curriculum of primary schools, providing training and retraining of primary school teachers in foreign languages, taking into account and solving the problem of ensuring consistency and continuity in language teaching at the level of primary and secondary education.

It was hoped that in time a consistent national policy on language education at school would eventually be developed, which would contribute not only to students' successful mastery of a foreign language but also to their personal development, including awareness of regional and international identity.

In general, the analysis of pedagogical experience of early start in foreign language teaching in the UK shows: positive dynamics of the results of students' success in a foreign language at the level of secondary education; increasing the motivation of students to learn a foreign language, the formation of a positive attitude of students to its study; the importance of learning a foreign language for general education, upbringing and development of children; the need for careful didactic development and pedagogical implementation of foreign language teaching at the level of primary education, as well as to ensure consistency and continuity in the curriculum of the subject at the level of secondary education.

\section{References}

Annan, N. (1962). Report on the Teaching of Russian. London: HMSO.

Burstall, C. (1970). French in the Primary School: Attitudes and Achievement. Slough: National Foundation for Educational Research in England and Wales.

Gamble, C. J., Smalley, A. (1975). Primary French in the Balance: Were the Scales Accurate. London: Modern Languages.

Hawkins, E. (1997). The Early Teaching of Modern Languages. A Pilot Scheme. London: CILT. Hotho, S. (1988). Introduction: Language Teaching and Language Learning. A Modern Relationship. Forum for Modern Language Studies. London: CILT.

Hoy, P. H. (1977). The Early Teaching of Modern Languages. London: Nuffield Foundation.

Johnstone, R. (1997). The Scottish Initiatives by Hawkins E. 30 Years of Language Teaching. London: CILT.

Lazaro, C. M. (1963). Report of Foreign Language Teaching in British Primary Schools, January to March. London: NFER.

Low, L., Brown S., Johnstone R., Pirrie A. (1995). Foreign Languages in Primary Schools: Evaluation of the Scottish Pilot Projects. Scottish: CILT.

Nisbet, J. (1970). Educational Research Methods. - London: University of London Press.

Penfield, W. G., Roberts, L. (1959). Speech and Brain Mechanisms. London: Oxford University Press.

Plowden, (1967). Children and their Primary Schools. London: HMSO.

Satchwell, P. (1997). The Present Position in England. London: CILT. 